\title{
Global Business Norms and Islamic Views of Women's Employment
}

\author{
Jawad Syed \\ University of Huddersfield \\ Harry J. Van Buren III \\ University of New Mexico
}

\begin{abstract}
This article examines the issue of gender equality within Islam in order to develop an ethical framework for businesses operating in Muslim majority countries. We pay attention to the role of women and seemingly inconsistent expectations of Islamic and Western societies with regard to appropriate gender roles. In particular, we contrast a mainstream Western liberal individualist view of freedom and equality - the capability approach, used here as an illustration of mainstream Western liberalism-with an egalitarian Islamic view on gender equality. While the article identifies an opportunity for this particular approach to reform patriarchal interpretations and practices of Islam toward gender egalitarian interpretations and practices, it also contests the notions of adaptation and well-being inherent within the capability approach. We suggest that a dialectical approach to understanding the relationships among religion, culture, and business provides a better guide to responsible business action in Muslim Majority countries than does the capability approach.
\end{abstract}

KEY WORDS: adaptation, capability approach, gender equality, Islam, Muslim women, well-being

\section{INTRODUCTION}

$\mathrm{I}_{\mathrm{i} /}^{\mathrm{s}}$ SSUES RELATED TO GENDER DISCRIMINATION are important for organizations (Karam \& Jamali, 2013; Kelan, 2008; Mayer \& Cava, 1993; Özbilgin, Syed, Ali, \& Torunoglu, 2012; Young, 1990). Globalization brings together different business systems and societal cultures (Bayes \& Tohidi, 2001; Metcalfe \& Rees, 2010) and different cultures conceptualize the socially appropriate role of women differently. Organizations operating in the United States and Europe, for example, face broadly agreed upon norms that support equal opportunity for women. The popular model in industrialized countries in the West is equal employment opportunity, which is based on the notion that there must be no gender discrimination or gender segregation in employment and other areas of public life. Organizations operating in many other countries may face broadly agreed upon social norms that 
support different roles for women; these roles may be seen by people living in the United States and Europe as discriminatory and subordinate to patriarchy.

More to the point, what gender equality means in practical terms is a subject of considerable debate, and especially so when considering how cultures and societies differ. Does gender equality mean that women and men should have the exact same roles in society, without any differentiation? Does it mean that all positions within society are open on equal terms to men and women? Does it mean that women and men are equal in some contexts (such as the workplace) and not in others (such as the home or within religious institutions)? There are myriad variations that can and do occur with regard to gender roles within and across countries. It might be possible, for example, to develop a framework in which women have equal access to employment opportunities, if they choose them, while playing a more subordinate role to men within the household, a situation which is common among American evangelical Christians (Gallagher \& Smith, 1999).

One of the most contested ethical issues for businesses is thus whether gender equality is a culturally neutral norm that all businesses and cultures ought to follow in every locale where they have operations. Mayer and Cava (1993) suggest that a Western perspective on gender equality should not be treated as ethical imperialism (treating one's own ethical standards as normative for all cultures in all times and places) in any pejorative sense and is therefore preferable to a moral relativist approach (proposing ethical standards are relative only to one's culture because there are no moral absolutes). However, not all cultures may subscribe to a particular set of principles and instead may prefer their own views on gender equality and the appropriate role of women in society (Syed \& Ali, 2011). Within Islam, for example, there seems to be an emphasis on diversity and complementarity of sex roles, rather than on exact sameness of women and men in all spheres of life. Islam declares that a man is responsible for economically supporting his family members, including his wife and children, while placing a high value on a woman's role as mother (Hussain, 1987). According to a hadith (a report of the deeds and sayings of the Prophet Muhammad): "Every man is a shepherd to his family, and a woman is the custodian of her husband's house and his children" (reported in Bukhari, 1959). Sidani and Thornberry (2013: 76) note that Islamic laws and social practices emphasize the role of the family in its extended form and encourage a set of obligations and expectations among family members. Also, Islam requires its followers to observe modesty; this requires a particular code of dress and interaction between non-mehram (i.e., not related) women and men (Quran 24:31). ${ }^{1}$

Businesses headquartered in the United States and Europe (among other countries in which gender equality is an expected norm) operating in Muslim majority countries (MMCs) in which gender equality is conceptualized differently therefore face a dilemma. On the one hand, they generally want to support norms of gender equality consistent with their home cultures and their stakeholders' expectations, as well as with legal requirements of their home countries. On the other hand, they want to be respectful of local or host cultures, especially when culture and religion are mutually reinforcing. The tension between norms thought to be universal and local cultural autonomy is a consistent theme in the business ethics literature. 
In this article, we seek to explore the issue of gender equality within Islam in order to develop an ethical framework for businesses operating in MMCs. Our focus is on the role of women and seemingly contradictory expectations of Islamic and nonIslamic societies with regard to appropriate gender roles. In particular, we contrast a particular Western liberal individualist view of freedom and equality - the capability approach, used here as an illustration of mainstream Western liberalism - with an egalitarian Islamic view on gender equality. Pioneered by economist and philosopher Amartya Sen and developed further by philosopher Martha Nussbaum, the capability approach offers an explicit ethics of well-being and equality, which scholars have generally applied in the context of international development (e.g., Gagnon \& Cornelius, 2000; Robeyns, 2002). In the last few decades, the capability approach has become highly influential as a philosophical framework for development policy at various international forums, including the United Nations where it has shaped the evolution of the human development index and gender development index.

We offer a partial counterview in this article that emphasizes an egalitarian reading of Islamic theology. Rather than simply rejecting the capability approach as "too Western" or "too secular," we seek here to illustrate how Islamic tradition and practice might usefully critique a Western-centric orientation of the capability approach while the capability approach simultaneously critiques particular patriarchal interpretations of and practices in Islamic tradition. In this pursuit, we follow the dialectical approach developed by Benson (1977) and expanded upon by Seo and Creed (2002). We also draw upon Gallagher and Smith's (1999) work in which conservative religious traditions often combine symbolic traditionalism and pragmatic egalitarianism, which further supports our proposal that a dialectical approach is useful with regard to gender, the capability approach and Islamic culture. We conclude with a discussion of implications for practice and future research.

\section{GLOBAL BUSINESS NORMS AND WOMEN'S EMPLOYMENT}

Modern Western approaches to women's employment are generally dominated by discourses and public policies related to equal opportunity and diversity management. Many countries have formulated laws to implement gender equality at work to ensure that women do not face any type of discrimination or harassment in the workplace. Organizations in such countries have in turn largely adopted the discourse of equal opportunity and diversity management for several reasons: to comply with legal requirements, to maintain legitimacy in the eyes of organizational stakeholders (Suchman, 1995), and to ensure that positions in organizations are occupied by the people who are most qualified to hold them. Scholarship on diversity and equal opportunity in modern societies such as the US, the UK, and Australia has highlighted a number of key obstructions in the way of equal opportunity, including but not limited to gender stereotypes, occupational segregation, pay gaps and the glass ceiling (Powell \& Butterfield, 1994; Syed \& Murray, 2008; Tatli, Vassilopoulou, \& Özbilgin, 2013). 


\section{Islam, Women and Modernity}

The term "modernity" has been used to refer to a world constructed anew through the active and conscious intervention of individuals (Giddens, 1990, 1991). In modern societies, the world is experienced as a human construction, an experience that gives rise to not only a new sense of freedom but also to a basic anxiety about the future (Eyerman, 1992). Seen from this angle, modernity is concerned with capitalism, industrialism, urbanism, and the democratic nation-state. It may also be seen as a breakdown of social values, traditional social order, and moral regulation (Durkheim, in Lukes, 1985).

In conceptualizing modernity, Weber (1958) focuses on the rationalization of the world where a society becomes dominated by norms of efficiency, calculability, predictability, and control. This results in dehumanizing rationalization where the average person is less important than the clock and the calculator. The most defining property of modernity, according to Giddens, is that we are disembedded from time and space. In pre-modern (or traditional) societies, space was the area in which one moved; time was the experience one had while moving. In modern societies, however, the social space is no longer confined by the boundaries set by the space in which one moves (Giddens, 1990, 1991). However, we argue in this article that an imaginative character of modernity and its dissociation from time and space may be problematic, for example, in cross-national transportation of ideologies and practices of equal opportunity.

Also of relevance here is Tönnies's (1971) distinction between societies based on Gemeinschaft (i.e., traditional community) and on Gesellschaft (i.e., modern commercial society). Gemeinschaft may by exemplified historically by a family or a neighborhood in a pre-modern (or traditional) society; Gesellschaft by a jointstock corporation or a state in a modern society. The Gesellschaft relationships in an urban and capitalist setting are characterized by individualism and impersonal monetary interests. Social ties in a Gesellschaft context are often instrumental and superficial, with self-interest and exploitation increasingly the norm.

We argue that a Western-centric framing of gender equality at work may face some issues and challenges when organizations seek to expand their businesses to non-Western countries. We focus our attention in this article on ethical and ideological issues that a Western (or modern) framing of equal opportunity may confront in MMCs. There are two reasons for our focus on this topic. First, with more than 1.6 billion followers, Islam is the second largest religion in the world (DeSilver, 2013); fifty-six countries of the world today are members of the Organization of the Islamic Conference. Second, Islam and Muslims are generally viewed (particularly in the West) as having an approach to gender relations much different from a Western, liberal approach to equal opportunity.

\section{The Capability Approach}

As an exemplar of Western philosophy, we focus on the capability approach and highlight some of the same tensions that exist between this particular approach and 
Islam, with a view to revealing any potential tendencies of contemporary business as points of tension with Islamic theology and interpretation.

In their description of the capability approach, particularly in their critiques of happiness and desire-fulfillment views of well-being, Sen and Nussbaum frequently refer to the notion of "adaptation." Sen (1992) notes that people who persistently live in adverse situations suffering different forms of deprivation may notwithstanding be happy or satisfied with their circumstances. Satisfaction for such persons may provide an inadequate informational space for well-being and quality-of-life evaluations. Nussbaum (2000) argues that long-term discrimination such as sex bias may affect individuals' values. She tackles this issue in her analysis of the limitations of subjective welfarism.

Sen's concerns about adaptation apply forcefully in the context of gender (in) equality (Qizilbash, 2006: 28). For example, women living in a highly inequitable society may be able to pursue only a very limited range of opportunity. Once having become accustomed to the inequities embedded in their society, they may find they enjoy what they have access to. Women's contentment with their lot is likely to distort the 'utility' calculus (Sen, 1995: 259-65). Our focus in this article is on the adaptation argument presented by Nussbaum (and as also by Sen)—i.e., the claim that modern values, such as the individual rights and socially atomistic kind of egalitarianism offered by Western theorists (e.g., Nussbaum), cannot be objected to on grounds that Muslim women accept certain uniquely Islamic understandings of their role because those women have improperly adapted to their particular social setting. (There is, however, some empirical evidence to the contrary, e.g., Muslim women's perspectives on their cultural and religious identity while living and working in Australia; see Syed \& Pio, 2010). By "egalitarianism" here we mean not that men and women are equal in worth and dignity — a proposition that we believe to be common to most people and religious systems but rather that the societal roles of men and women should be exactly the same. Instead, we consider it more useful as well as legitimate to consider the development of women's issues in Islam, on Islamic terms.

We argue that modernity and its values clash with some interpretations of Islam with regard to questions of women's employment. In fact, in some cases Muslim women themselves appear to reject modernity in favor of a uniquely Islamic view of their status. One temptation - exercised by writers such as Nussbaum-is to dismiss the acceptance by Muslim women of an alternative (i.e., non-modern, pre-modern), uniquely Islamic view of their status. This is the adaptation argument about false consciousness in effect. However, we consider the adaptation argument as untenable. On this point Bruckner (2009) argues that adaptive preference may be seen as regimented in response to an agent's set of feasible options. Bruckner argues that many adaptive preferences that other scholars have cast out as irrational preferences may be seen as fully rational preferences worthy of pursuit by taking into account the agent's own appraisal of the adaptive preference.

Analogously, Hakim's (1998, 1999, 2003) Preference Theory seeks both to explain and predict women's choices regarding investment in productive or reproductive contributions to society. It suggests that women fall into three main groups: women 
who prefer a work-centered lifestyle, often remaining childless by choice (about 20 percent); women who prefer a home-centered lifestyle, often having many children and little paid work (also about 20 percent); and the remaining majority of women who are adaptive, combining paid work with raising children. Preference Theory is founded on the idea that modern family models are diversifying both in form and function, and that individual desires regarding family-work orientations need to be respected by the larger society. Family structures can be categorized as gender egalitarian, compromise or role segregated, but these labels focus on the relationship between husband and wife. It is also important to consider the work orientation of the female member of the marital relationship, as she is currently being held responsible for both work and home duties.

Sen's notion of adaptation has been critiqued by Sugden (2006), who argues that the idea that "ethical theorists can claim to know better than some particular individual what is good for [him/] her seems to open the door to restrictions on freedom" (Sugden, 2006: 34). Sugden cites Sen's (1999) emphasis on individuals' capability to lead the kind of lives they have reason to value. The "reason to value" formula is important for Sen because capability cannot be evaluated entirely by reference to an individual's actual desires. Sen suggests that certain functionings are valuable to all human beings, whether they are desired or not. But Sen does not seem to evaluate a person's capability in terms of a standard of value that is wholly external to her. Sen's solution is to invoke a universalistic concept of "reason." The suggestion is that the standard of value is one that, in the light of reason, each individual would endorse (Sugden, 2006: 37-38).

Since Sen avoids making substantive claims about what people have reason to desire - in comparison to the more ambitious approach adopted by Nussbaum - Sugden (2006) uses Nussbaum's (2000) texts to illustrate the scope that the capability approach offers for some people to impose on others their understanding of what is worthwhile in life. The core of Nussbaum's work is a list of "central human capabilities," which should be guaranteed to every individual. Sugden wonders if it is possible to accept the reality of adaptive desires without allowing collective judgments about rational desires to override individuals' actual desires (Sugden, 2006: 41). He notes that Nussbaum is equally dismissive of the prospect of objection to her favored principles from the perspective of any particular religion:

Given that the religion has agreed to sign on to a constitution of a certain type, it will have to figure out how to square this 'overlapping consensus' on public political matters of basic justice with the rest of what it teaches. (Nussbaum, 2000: 232)

It seems that Nussbaum is not thinking about how to design a constitution that can be agreed to by everyone (or every religion), given one's ideas about what is valuable. Indeed, it is unclear who the "we" who will have to "figure out" how to square religion with the supposed overlapping political consensus on matters of political justice is in this context. Instead, she is imagining a world in which everyone has already agreed with her, a perspective that is quite problematic (Sugden, 2006: 51). Such an all-or-nothing approach to political matters and social mores is, we will argue 
in a subsequent section, inconsistent with a dialectical approach to understanding the relationships among religion, culture, and business.

While Sen seems to be ambiguous or half-apologetic on his notion of social choice, Nussbaum (2001) considers her list of central human capabilities to be a free-standing "partial moral conception," explicitly introduced for political purposes only and without any grounding in metaphysical ideas of the type that divide people along lines of culture and religion (Nussbaum, 2001: 13). She suggests that it makes sense to take the issue of social justice seriously, and to use a norm of justice to assess the various nations of the world and their practices (Nussbaum, 2001: 18). However, there are some obvious problems with such notion of "a norm of justice."

For example, adaptation is not always problematic. It can at times be an intelligent and free process, based on people's social experiences and learning in life (Conte $\&$ Castelfranchi, 1995). A predominantly negative picture of adaptation may result in discounting the role of individual agency in helping women and men actively identify and pursue their intelligent preferences in life. Previous research shows that subjective indicators play an important role in defining people's well-being (Easterlin, 2003; Veenhoven, 2000, 2002). In other words, adaptation may represent a dynamic process that can be deployed and interpreted in numerous ways. However, such interpretation would need to be based on an understanding of the context, taking into account issues of individual agency and social choice, something that may be hard to achieve through a universalistic notion of well-being. Indeed, there is always a possibility that some people—critics such as Nussbaum — plausibly could hold themselves aloof from their own adaptation and thus critique the adaptation of others. We now turn to a specific context, namely the role of women in Islamic societies.

Instead of subscribing to the adaptation argument, we take a more nuanced view of the role of women in Islam, attending to its complexities and articulating how it has developed through a dialectical engagement with modernity (and how that engagement generates a sub-theme of contrasting versions of Islam itself, i.e., egalitarian vs. non-egalitarian Islam). This more complex view of women in Islamic society in turn may provide advice for the practice of business in a large part of the world, advice which would have been missed had we either simply rejected Islamic views as adaptation/false consciousness, or had we simply assumed a patriarchal caricature of Islam's view of women.

\section{THE ROLE OF WOMEN IN ISLAM}

In this section, we provide an overview of the role of women in Islam in the light of the Quran and other Islamic texts. We also explain how the interpretation of the Quranic verses regarding the role of women remains subject to various historical and contextual influences. Like other religious traditions, Islam lends itself to multiple interpretations of doctrine that are plausible in different contexts. In the same way that there are multiple ways of being Christian, for example, so are there multiple ways of being Islamic. As we will seek to demonstrate, the archetypical reading of Islam from outside the tradition with regard to the role of women is quite different than that offered by the Quran and enacted within much of the Islamic world. 
We acknowledge the fact that the actual text of the Quran is in Arabic, and thus there are some radical differences within Islam with respect to its interpretation and translation. Barlas (2002), for example, points towards the dominant patriarchal influences on Quranic interpretation and translation. In her own commentary on the Quran, Barlas challenges oppressive readings of the Quran and offers "a reading that confirms that Muslim women can struggle for equality from within the framework of the Quran's teachings, contrary to what both conservative and progressive Muslims believe" (xi). What we seek to do is neither to read egalitarianism into the text where it is not present or to pick minority views of proper Quranic interpretation that fit our analysis, but rather to identify plausible egalitarian interpretations that demonstrate scholarly and popular (within some contexts) support for egalitarianism within Quranic interpretation and Islamic tradition.

\section{Egalitarian Injunctions in the Principal Texts of Islam}

While the modern Western discourse on women's rights in the main emanated from the first wave feminism during the nineteenth century and early twentieth century in the UK and the US, the language of rights (haqq) in the Islamic literature can be traced to the seminal Islamic period and texts, almost 1400 years ago. The Quran ${ }^{2}$ declares the creation of opposite genders as a part of divine scheme, a matter of reflection $(51: 49,36: 36)$. The good deeds of all humans will be rewarded irrespective of their gender (16:97). There are numerous verses in the Quran which establish equality between men and women. One such verse is: "O mankind! reverence your Guardian-Lord, who created you from a single person, created, of like nature, His mate, and from them twain scattered (like seeds) countless men and women;- reverence Allah, through whom ye demand your mutual (rights), and (reverence) the wombs (That bore you)" (4:1). It may be noted that the parentheses are used by translators to explain a point which is not too clear in literal translation of the Quran from Arabic to other languages. In other verses, the Quran says "Women have rights similar to the rights against them" (2:228). Women and men possess equal rights for work and compensation." and "Never will I suffer to be lost the work of any of you, be he/she male or female: you are members, one of another" (3:195).

Similar emphasis on women's rights can be found in the hadith. For example, in his famous sermon at the eve of "the Farewell Pilgrimage" (A.D. 632), the Prophet particularly mentioned the special place for women in an Islamic society. Note that the Prophet used the Arabic word haqq (right) to emphasize mutual rights of man and woman on each other:

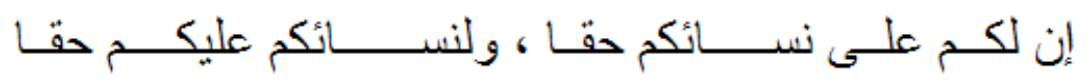

O People! It is true that you have certain rights with regard to your women but they also have rights over you. ... Do treat your women well and be kind to them for they are your partners and committed helpers. (Prophet's Last Sermon, n.d.) 
However, the Quranic notion of equality appears to be based on gender differentiation, not on identicality. For example, Islam recognizes a woman's economic rights, such as her right of inheritance, which is enshrined in her share of her parents' as well as her husband's properties, according to Islamic sharia, ${ }^{3}$ though it is a man's sole responsibility to provide adequate economic resources for his family including his wife and children (Hussain, 1987). ${ }^{4}$ It would appear that gender differentiation within Islam is itself socially constructed and changeable over time. According to Barlas (2006: 7):

The Quran does not even associate sex with gender. That is to say, it recognizes sexual (biological) differences but it does not assign them any gender symbolism. There is thus no concept of gendered man or woman in the Quran. Not a single verse links men and women to a specific division of labor or define their roles as a function of their biology, or say that biological differences make women and men unequal.

Perhaps with an eye to improving individuals' overall capabilities, Islam declares seeking education a religious duty, which is equally binding on women and men (Ibn Majah, 1952). Islam also allows women to be engaged in economic activities including operating their own businesses (Hassan, 1994). For example, Khadija, the Prophet Muhammad's first and most revered wife was an eminent businessperson in ancient Arabia. In fact, Muhammad was in her employ before marrying her (Syed \& Ali, 2005). There are several similar examples in Islamic history which suggest that female companions of the Prophet used to be engaged in business activities in the city. The second caliph, Umar ibn Al-Khattab, appointed a woman, Ash-Shifaa' bint Abdullah, as the supervisor of markets in Madinah. Certain other Muslim women such as Khaula, Lakhmia, Thaqafia, and Bint Makhramah traded perfumes. The wife of Abdullah ibn Mas'ud met her expenses by manufacturing and selling handicrafts. A female companion named Quila said to the Prophet, "I am a woman who buys and sells things." Then she asked several questions about buying and selling. Thus, business was a legitimate activity of the female companions of the Prophet (Crescentlife, n.d.). Abu-Shuqqah (1990), an eminent contemporary scholar, mentions in his voluminous work, "Women's Liberation at the Time of the Prophet," more than 300 authentic traditions of the Prophet that confirm women's full participation in social activities during the Prophet's time.

\section{Historical and Contextual Interpretations}

Mernissi (1996) has shown how many Muslim men tend to misread the verses that extended certain inalienable rights to women, e.g., women's rights in marriage and also to own a property. By the third century after the Prophet, even the Quranic exegesis (tafsir $r$ ) showed that the egalitarianism once associated with Islam had lost its "subversive connotation." This view appears to be consistent with the argument that the egalitarian impulse of any religious system loses steam as it becomes institutionalized (Anderson, 2004).

Marlow (1997) argues that as early as the second century after the Prophet Muhammad, Islamic scholars had begun to weaken "the egalitarian impulse in various 
parts of tradition," by justifying hierarchical models of family and tribal system in a society that was supposed to promote egalitarianism (Marlow, 1997: 66). Islamic scholars who had "gained incontestable possession of the moral high ground" failed to "translate the anti-hierarchical and anti-authoritarian moral at the heart of their scholarly tradition into an active social and political opposition" (Marlow, 1997: 93). Instead, they sought to justify those pre-dominant hierarchies and acted as subservient to patriarchal influences. This view is also shared by Al-Hibri (1982), who asserts that the institution of patriarchy co-opted Islam after the death of the Prophet.

Other scholars (e.g., Armstrong, 1992; Lewis, 1995) have noted that Islam brought a general improvement in the position of women in ancient Arabia, e.g., Islam endowed women with rights to property and inheritance, respect in social life, protection against ill treatment of their husbands. Islam prohibited the practice of female infanticide, which was previously sanctioned by customs in pagan Arabia. Armstrong notes:

We must remember what life had been like for women in the pre-Islamic period when female infanticide was the norm and when women had no rights at all. Like slaves, women were treated as an inferior species who had no legal existence. In such a primitive world, what Muhammad achieved for women was extraordinary. The very idea that a woman could be witness or could inherit anything at all in her own right was astonishing. (Armstrong 1992: 191)

However, much of this impetus was lost and original message of Islam was modified "under the influence of pre-existing attitudes and customs" (Lewis, 1995: 210). Hussain (1987) argues that Islamic scholars in the classical age terminated the agency of the woman and, in order to guard her chastity as well as the chastity of man, segregated her entirely from male society. In that process, the woman was reduced to a mere sentinel of male chastity, a tradition amply reflected in strict institutions of seclusion and veiling. Mernissi (1987) argues that the Prophet's efforts were aimed at renouncing the "phobic attitude" then prevailing toward women and that the Islamic message introduced hopes of gender equality in the treatment of women (Mernissi, 1987: 81). After the death of the Prophet "very quickly the misogynistic trend reasserted itself" (Mernissi, 1987: 75). In order to rescue monotheism after the Prophet's death, a compromise was deemed necessary with the Arab patriarchal tradition of that period. The male elite, including some within the Prophet's companions, began to "fabricate" misogynistic hadith to their own benefit (Mernissi, 1991: 45-46).

\section{Islamic Feminist Interpretations}

Islamic feminist scholars argue that the Arabic text of the Quran is "full of subtleties" open to both liberal and conservative interpretations (Minai, 1981: 20). Most Muslims do not understand Arabic and are dependent on Islamic scholars to develop an understanding of Islamic traditions. Furthermore, different readings of the same texts yield "fundamentally different Islams" (Ahmed, 1992). Thus, what Muslims read the Quran to be saying is a function of who reads it, how, in what contexts (Barlas, 2002), and also the ethos of the society in which the interpretation is embedded. 
Ahmed (1992) uses the Quran as a heuristic device to construct abstract egalitarian principles of the faith. Her interpretation gives prominence to the "egalitarian voice" of Islam and dismisses its "legal voice" as derived from the foreign (i.e. non-Islamic) patriarchal influences. Ahmed argues that the legal voice sanctified the subordinate position of women in the social-legal edifice of Islam. In support of her argument, Ahmed highlights the fact that in the years immediately after the death of Muhammad, women such as Ayesha and Umm-Salma played a key role in transmitting the hadith and were among the authors of the verbal texts of Islam (Ahmed, 1992: $64,73)$. She argues the egalitarian voices of Islam were largely silenced under the influences of various patriarchal cultures of the conquered lands where the Muslim Arabs were assimilated and adopted the traditions of the dominant classes.

Barlas (2001) notes that the Quran treats women and men as equal yet diverse. She refers to an emerging consensus among feminists that simple equality principles have "proven inadequate for feminist practice" especially in the "area of sexuality" (Miles, 1996: 49). However, in her treatment of gender diversity in the Quranic teachings, Bralas does not use "different" to imply "unequal." She points to a growing literature that suggests that treating women and men as diverse human beings with diverse roles does not in itself amount to treating them unequally, particularly if differences in treatment are not premised in claims about sexual (biological) differentiation (Hekman, 1990; Keddie, 1996).

Islam absolves women, in general, of economic responsibility within the household, an option which is left to the woman's personal choice and circumstances. Women's free choice to participate in economic activities or to concentrate on their domestic duties is, however, in stark contrast to men's position in Islam. For men, economic activities are not a matter of choice but a religious responsibility (Hussain, 1987). ${ }^{5}$ Islamic feminists such as Al-Hibri (1982) and Hassan (1999) acknowledge the Quranic description of men as qawwamun (breadwinners or those who provide a means of support or livelihood). Thus clearly Islamic traditions place a high value on individuals' family-related roles, particularly on women's roles as mothers.

Because women are not religiously duty bound to economically support their families, they are generally less likely to seek paid jobs unless forced by their special circumstances or for personal fulfillment. For example, in their study of working women in Iran, Ghorbani and Tung (2007) suggest that since more women work part-time in order to take care of their families, this exacerbates income disparity. This suggests that female economic activity rates, particularly when such rates are biased toward work in the formal sector of the economy, may prove an inadequate means of judging gender equality in an Islamic context. An adequate measure could be the one which does not confine evaluation of gender equality in the domain of economic organization but takes a holistic, context-specific view of the definition and measurement of gender equality (Syed, 2008).

\section{The Workplace Roles Held by Muslim Women Today}

However, it must be acknowledged that, over many centuries, the special protective provisions for women have, under the patriarchal influences that pervade the Islamic 
faith, tended to result in religious practices that are particularly disadvantageous to working women (Ali, 2013; Barlas, 2001; Hassan, 1994). A narrow interpretation of female modesty and gender segregation has historically resulted in Muslim women's confinement within the four walls of their houses, such as in Pakistan and India (Syed, Ali, \& Winstanley, 2005). Consequently, working women in MMCs are more likely than their sisters in the West to face gender discrimination in the labor market.

Mernissi (1996) argues that the institution of paid employment in Muslim societies, Arab countries in particular, is a traditional domain of men, who consider it a matter of religious duty as well as male pride to support their wives. It is not unusual to find men who feel "insulted if one asks them whether their wives work outside the home" (Mernissi, 1996: 64). A woman in paid employment is a traumatizing idea for such men, particularly those from lower literacy backgrounds. A narrow interpretation of Islamic female modesty has particularly served to remove women from the public space including paid employment. Ali (2000) notes that general and vaguely phrased Quranic verses regarding modesty in behavior have been interpreted in a variety of ways by male Muslim scholars, "a process that many writers believe [has] led to an ever-increasing exclusion of Muslim women from the public sphere of life" (Ali, 2000: 76). Such patriarchal traditions seem to pose a major challenge to women's freedom and capability, including their freedom to pursue professional careers in Muslim societies.

Thus, despite the cultural differences that distinguish countries from Malaysia to Bangladesh and from Pakistan to Iran to Saudi Arabia, and all across Africa, a patriarchal interpretation of religion is practiced in most of these societies, with varying degrees of restrictions on women's mobility and employment. Indeed, there is an internal diversity even within the known Islamic sharia-based societies such as Saudi Arabia, where women are not allowed to drive cars, and Iran, where women are accepted in the air force and a woman currently holds the position of vice-president of that country. Ghorbani and Tung (2007) demonstrate that some factors contributing to a glass ceiling faced by working women in Iran are universal, i.e. are not unique to Islamic societies, while other factors are specific to the institutional/socio-cultural context of that country.

There is some macro-level evidence to suggest that the way women are treated in MMCs, including in workplaces, remains predominantly influenced by local interpretations of and approaches towards Islam. For example, Iran is one such country where the Shi'ite Islamic institution of ijtihad (critical interpretation of religion) seems to have resulted in better opportunities for women at least in relation to the status of women in the Sunni or Wahhabi dominated Saudi Arabia or the Taliban's Afghanistan. Women in Iran are reported to hold important positions in universities, in government jobs, in culture and other fields. They've entered the workplace as business owners, doctors, and cab drivers and they've become involved in politics (Zind, 2009). The Iranian census (2006) shows that the female share of the labor force is about 20 percent. About one third of Iran's female labor force is in professional jobs, concentrated in education, healthcare, and social services. About 50 percent of the female work force is in professional and technical employment (54.5 percent with executive positions included) (Moghadam, 2009). Anecdotal evidence suggests that 
the Iranian government takes particular care to facilitate working women's family responsibilities. For instance, if a woman has a baby, she can go home early, and her wages will not be cut. She can also take six months leave with pay. There is also a considerable female participation in politics. Furthermore, contrary to the popular belief, most of the universities in Iran are co-educational. Until class five, education is compulsory and free up to the college level. After completing high school in the rural areas, there are hostels in the city where students can go and continue their studies. Adults are also encouraged to study and facilities are provided to them. While there were fewer women in higher education before the Islamic revolution, now there are 67 percent women in higher educational institutions as compared to 33 percent men. This also means that there is likely to be a greater representation of women in parliament and in the workplace in the near future (Hyder, 2008).

Bangladesh offers another example of an MMC in which the socially acceptable roles of women have expanded. Labor force participation rates for females in Bangladesh increased sharply from 8 percent in FY1984 to 29.2 percent in FY2006. Every year 600,000 women are added to the labor force. With gender parity in primary and secondary education, more educated women are joining the labor force (Hua, 2008). It may be noted that since its independence from the "Islamic Republic of Pakistan," Bangladesh chose "People's Republic of Bangladesh" as its official title, possibly indicating its inclination towards a secular and more inclusive version of Islam and the state. This inclusive stance may be seen as contributing to the enhancement of women's status in Bangladesh, and indeed Bangladeshi politics have been dominated by two women who have taken turns serving as prime minister. The newly independent state in 1971 had a dream of a new society, for which the state created a Constitution that focused on principles of equality and liberty. An egalitarian understanding of Islam, it would appear, then enabled the state to proceed to ratify several international conventions and participate in international conferences for women (World Bank, 2008).

\section{Movements for Reform within Islam}

The foregoing discussion suggests that, in terms of gender relations in Islam, the real challenge lies in how narrow and patriarchal interpretations and practices of religion could be reformed to bring about gender equality. Of course, the definition of "gender equality" is itself socially constructed, and what would appear to be from a Western and/or secular perspective to be typical of patriarchy would be understood quite differently by both women and men within the Islamic context. Beeku and Badawi (2005) insist that normative Islam rejects sexism in business as well as in other areas of life. (Normative Islam is what Muhammad as a Prophet revealed through the Quran and also through the examples he gave in words and deeds. However, given the differences of opinion regarding interpretations of the Quran and the hadith, normative Islam remain a contestable goal which different interpretations are trying to reach.) Beeku and Badawi note that piety, not gender, is the only legitimate basis for superiority within normative Islam (Quran, 49:13). Yet, it is common knowledge that Islam's normative teachings are inconsistently 
followed in the Muslim world; they are usually set aside either by an extremely conservative approach or by cultural bias (UNDP, 2002).

Islamic feminists have argued for the need to unread patriarchy from the Quranic interpretations. While their arguments remain hotly contested in the "mainstream" or "male-stream" Islamic scholarship, there appears an ever increasing number of Islamic feminist voices from within the pale of Islam. Barlas (2002), for example, has endeavored to recover the scriptural basis of gender equality in Islam through un-reading patriarchy from the Quranic interpretations. She offers a compelling argument about why Islam is not a patriarchy and why Muslim women and men can struggle for equality from within an Islamic framework. Barlas argues that the reason Muslims have failed to read the Quran as an anti-patriarchal text has to do with "who has read it (basically men), the contexts in which they have read it (basically patriarchal), and the method by which they have read it (basically one that ignores the hermeneutic and theological principles that the Quran suggests for its own reading)" (Barlas 2002: 1).

Mernissi (1987) has exposed the ideological links between the Islamic normative system and the practices of patriarchy. She argues that historical Islam has deeply ingrained the fear of female sexuality in the male consciousness. Mernissi describes patriarchy in Islam as an organized system which treats gender equality as violation of Islam's (pre-supposed) premise that women must remain under the authority of a male relative (father or husband) and that they must be spatially or socially confined and excluded from matters other than those pertaining to family (Mernissi, 1987: 19). Similarly, Hussain (1987: 4-9) argues that the Quranic verses "men are a degree above women" (2:228) and that "men are in charge of women" (4:34) only refer to man's position as head of the family consisting of his wife and children, whom he is duty bound to maintain. The additional charge, however, increases man's liabilities towards woman, makes woman immune from financial liabilities thus magnifying her importance as a human being. Hussain argues that a woman has like a man "an independent individuality and is economically, socially and politically identifiable as an entity different from her husband, father or son with right to own property, earn money, vote at elections, hold electoral or other public offices, and protect her legal and constitutional rights or interests" (Hussain, 1987: 1). Hussain concludes that instead of being subject to the rule of segregation imposed on her by social customs, a woman may appear in public in modest dress, with her face unveiled and hands open. We now turn to a critique of the capability approach and offer a dialectical approach to analyzing the role of women within Islam, with particular attention to what our analysis indicates for businesses seeking to act ethically within an Islamic context.

\section{DIALECTICAL ANALYSIS AND THE ROLE OF WOMEN IN ISLAM}

We start our analysis here with a restatement of the problems with the capability approach vis-à-vis the role of women and Islam. We have noted that the capability approach is implicitly built on a Western and secular perspective, which creates the possibility of cultural imperialism if applied uncritically. Further, the capability 
approach fails to account for the choices that people within Islamic societies freely make. Any assumption that women within Islamic societies make choices based on a supposed false consciousness that allows them to engage in adaptation in order to feel better about their subjugation may oversimplify the relevant issues while imposing an external perspective on another culture and religious system. A more nuanced analysis that accounts for differences across Islamic cultures and insights from the capability approach offers a better way forward.

However, an honest interpretation of Islamic tradition does indicate that there are real differences in how the acceptable roles of women are defined, although such definitions differ across MMCs and are generally changing within the Islamic world. One way to bring together the capability approach and the Islamic tradition is through dialectical analysis (Benson; 1977; Seo \& Creed, 2002). Through dialectical analysis, a mutual critique between the capability approach and the Islamic tradition can occur that allows for a new synthesis and framework for understanding the economic roles of women within Islamic societies.

Benson (1977) proposes four basic principles of dialectical analysis:

1. Social construction, which is the social process through which orderly and predictable relations are produced and reproduced;

2. Totality, which represents the interconnectedness of these built up social patterns;

3. Contradiction, in which various ruptures occur and inconsistencies among and within established social arrangements are found;

4. Praxis, the free and creative reconstruction of social patterns on the basis of a reasoned analysis of both the limits and potentials of present social forms.

The key advantage of dialectical analysis in the present context is that it defines social roles and cultural understandings as socially determined. No society, culture, or religious tradition is static. Rather, the taken-for-granted patterns of interactions at one point in time change-albeit slowly — as new insights emerge based on ruptures and contradictions within the society. Seo and Creed highlight the particular importance of contradiction and praxis with regard to creating institutional change (see Seo \& Creed, 2002: 232, Figure 2A). We, therefore, propose that institutional contradictions between patriarchal readings of Islam and (educational and economic) institutions that support an expanded role for women do (and will) generate a new praxis and associated institutional change, although at different speeds in different Islamic societies.

In order to understand how this process might occur, we now introduce the ideas of symbolic traditionalism and pragmatic egalitarianism introduced by Gallagher and Smith (1999). In their study of American evangelical Christianity, Gallagher and Smith found that evangelicals (the subset of Christians who espouse more conservative interpretations of the Bible) combined elements of traditional gender roles with pragmatic concerns about supporting the family financially. They found generally that "both women and men saw men as ultimately being responsible for the family, a responsibility that ought to earn men the respect and deference of their wives and children" (Gallagher and Smith, 1999: 217). Like Islamic tradition, male 
responsibility in the economic sphere and in the governance of the home is widely agreed upon within American evangelicalism.

However, Gallagher and Smith also found a high degree of pragmatism among American evangelicals, both men and women. Economic realities in the United States often require families to earn two incomes in order to make ends meet. (Gallagher and Smith do not address the issue of women's capabilities being a rationale for the paid work of women, which as we will argue contributes to how women's roles within Islamic societies are changing.) Evangelical men and women account for this seeming contradiction - men are responsible for material wellbeing but women often need to work - by emphasizing accountability for spiritual welfare and governance of the home as a male responsibility and deemphasizing men's roles as sources of financial support for wives and families. The symbols of male headship—leading prayers, making decisions about what to do with the household's incomes-remain as guiding principles that are to be honored by both men and women in this context, at least rhetorically. However, Gallagher and Smith also note that women's employment may itself "be transformative, reshaping the practice of gender within evangelical families" (Gallagher and Smith, 1999: 225). Women's paid employment outside the home thus reshapes their understandings of what is and is not acceptable with regard to gender roles. However, it is not necessary for either women or men to use the language of gender equality for there to be increasing gender equality.

Thus, we propose that it is entirely possible for someone (or for that matter, an institution) to be rhetorically in favor of male headship and practically close to egalitarianism. Households, much like organizations, religious systems, and societies, will often tend towards a pragmatic approach in solving issues such as gender roles. While robust rhetoric in favor of gender egalitarianism in all spheres of society may feel satisfying (particularly to outsiders), it may not always be the best approach to bring about social change. Rather, our approach is consistent with both the freedom of societies to define what is meaningful and appropriate while also making provision for accommodation to wider social trends and interactions with other social actors. In this way it is also consistent with the dialectical approach we previously outlined. Our point is not that activism and advocacy of gender egalitarianism is wrong or inherently imperialistic from an ethical or a cultural standpoint. Rather, we first propose that ethical analyses of gender egalitarianism (or for that matter, other ethical issues which interact with cultural and religious systems) must be sensitive to local differences in how people define meaning. Second, from the standpoint of creating social change, approaches that are more pragmatic and dialectical are more likely to be successful than approaches that rely on confrontation.

We think that the distinction between symbolic traditionalism and pragmatic egalitarianism is helpful for understanding how the capability approach and Islamic tradition might critique each other and thus bring about a new synthesis with regard to gender roles. We start with the proposition that social construction and totality with regard to gender roles within Islamic societies has traditionally supported a role for women that largely excluded their participation in the economic sphere. However, as have we pointed out, much of what has been traditionally cast as the orthodox interpretation of the Quran with regard to gender roles has been based less 
on a balanced interpretation of the Quran as it is written and more based on cultural traditions outside of the text. (We note that a selective and patriarchal reading of the New Testament of the Christian scriptures might lead to a similar conclusion about women's roles; see, for example, St. Paul's letter to the Ephesians as an example of a text that has been lifted out of context to justify female subjugation; Wills, 2006).

What has been and is occurring within Islamic societies is contradiction, the third part of Benson's dialectical framework. Contradiction has been occurring in two ways. First, there has been a recovery of the latent egalitarian ideas within the Quran, which have been deemphasized within much of the dominant patriarchal theology. However, the inherent contradiction of not including the Quran's ideas about gender egalitarianism has become exposed by both theologians working within the tradition and by the recognition of women's capabilities in the economic sphere. Further, to varying degrees Islamic societies have been affected by the global feminist movement. However, some of the freedoms inherent to the capability approach are not suitable for the Islamic context; for example, sexual freedom. Other parts of the capability approach, such as economic opportunity, are increasingly compatible with Islamic tradition as that tradition is being reinterpreted by theologians and individual men and women. When businesses provide economic opportunities to women, they are contributing to the process of contradiction that in turns leads to a new synthesis.

The effects of contradiction — cast by Benson as praxis—will not lead to discarding Islamic tradition or to conceptual gender equality as it would be conceptualized within Western, Christian, or secular societies. Rather, the parts of the capability approach that are most suitable for Islamic societies-mostly focused on specifically economic roles-are likely to integrate, albeit at different speeds and to different extents based on how different countries currently conceptualize the "appropriate" role of women. However, we would propose that for many societies the outcome observed with American evangelicalism-symbolic traditionalism and pragmatic egalitarianism - is likely to occur. Modesty of dress is one element of symbolic traditionalism that is likely to remain, along with the rhetoric (and perhaps the reality) of male headship within the home. However, outside of symbolic traditionalism, women's capabilities will allow them greater economic roles that are nevertheless consistent with Islamic culture and the mainstream readings of the Quran.

In short, moves toward gender equality are likely to continue within the Islamic context, albeit at different rates and in different forms in different MMCs. This is not to say that gender equality will be conceptualized in the same way that it is in the United States and Europe; this is unlikely to occur in the near or even distant future. However, we have noted that the latent egalitarianism and effects of ideas like the capability approach do have (potential) effects on gender roles within the Islamic world, although these effects will unfold differently across countries. The balance that one society strikes between symbolic traditionalism and pragmatic egalitarianism will be different than that struck by another society, but both balances might well be consistent with Quranic interpretation and the broad outlines of the capability approach.

We also note our analysis offers an implicit critique of the capability approach. We previously noted that the capability approach is implicitly built on a Western 
and secular understanding of politics and ethics, with a potential to render "other" intelligent understandings and forms of gender equality as forced "adaptation." Just as patriarchy is increasingly being unread out of Islamic theology, so must a Western and secular bias be unread out of the capability approach. Some elements of the capability approach will be applicable to all societal contexts and others will not.

\section{EFFECTS OF THIS ANALYSIS ON BUSINESSES OPERATING WITHIN ISLAMIC SOCIETIES}

We conclude with a discussion of how our analysis might affect businesses operating within Islamic societies. First, we suggest that if the adaptation thesis is in part wrong, there are significant implications for corporations as they address cultural conflicts. Second, we suggest that corporations may play a role with regard to engagement with Islam during the process of dialectical development previously discussed. In this section we analyze two distinct issues within Islam as they relate to women's employment: the veiling of women, and work-life balance. Veiling deals with how women choose to present themselves. Work-life balance implicates gendered relations in the home as they affect women's lives in the workplace.

We have previously discussed the adaptation thesis at length, suggesting that one of the concerns that it raises in an Islamic context is that it implicitly privileges Western and individualistic understandings of the choices that women and men should make. Following Sugden (2006), we propose that avoiding paternalism with regard to what choices are acceptable helps corporate decision makers better understand how to interact with belief systems that are seemingly foreign to them. Choices about how to present oneself in public — as is the case for various gradations of female veiling - are deeply personal and often connected to religiously informed beliefs about modesty. Interestingly, in a later book about religious intolerance and fear, Nussbaum (2012: 128, emphasis added) in advocating for broad freedom from women to veil themselves stated that "[o]ne thing that Americans and Europeans need to face squarely is the fact that some people do actually choose lives involving authority and constraint."

Although a company headquartered outside of the United States and operating in an Islamic society might not expect that female veiling to be "typical" of the self-presentation of women, veiling should not be prohibited by that company. On matters such as self-presentation and dress-especially when they are connected to religious understandings - companies should give as much latitude as is practical. On this point Moore (2007) notes that the meaning that Muslim women themselves ascribe to veiling (female modesty, adherence to religious beliefs) is often quite different than that ascribed by outsiders to Islam (subjugation of women). Our critique of the adaptation approach suggests that while the practice of veiling may be seen by some as evidence of female subjugation and patriarchy, Muslim women who perceive that veiling is consistent with their religious identity should have the freedom to do so in the workplace-no matter how such choices might be perceived by others. An organization wanting to forbid or limit female veiling on the grounds that it would affect business operations would face a high burden of proof. Rather, 
a company wanting to promote equality for women in the MMC context should "create ample opportunities for them, and see what they actually do" (Nussbaum, 2012: 127) rather than forbid veiling or ascribe patriarchal meaning to the practice.

Similarly, with regard to work-life balance, there may be conflicts about the understanding of the "proper" role of women, both at home and in the workplace, between Islamic and non-Islamic societies. We noted previously that within Islam, the role of women as mothers is paramount and that Quranic notions of equality are based on gender differentiation rather than strict equivalence of roles within the home. An approach to understanding work-life balance built on an adaptation analysis would negatively cast the choices of women to balance work and family in ways that place the latter as primary as evidence of patriarchy. Our analysis offers a different conclusion: such choices can be understood as being made freely by women if they are based on their self-chosen religious identities. Muslim women might make different choices about work-life balance based on their self-definition as Islamic, and organizations have obligations to honor those choices. This might mean, for example, that the definition of "gender discrimination" used in Western societies would have commonalities and differences when applied in an Islamic context. For example, discrimination against women would be wrong in both contexts, but organizations might need to offer Muslim women reasonable accommodations that allow them to balance home and work.

We conclude with an analysis of the role corporations should (and should not) play with regard to promote gender equality within Islamic societies. Scherer and Palazzo (2007) draw a contrast between positivist and post-positivist schools of corporate social responsibility, criticizing positivist CSR because of its instrumental focus and lack of normative sophistication and post-positivist CSR because of its relativism and utopianism. They propose that corporations instead become political actors in a globalizing society, suggesting that (Scherer \& Palazzo, 2007: 1098) "they are not just addressees of regulation but also authors of rules with public impact. Applied to CSR, this means that the issue is not so much the realization of an ideal speech situation within processes of corporate decision making as it is the embedding of the corporation in democratic processes of defining rules and tackling global political challenges." In their institutional perspective on gendering CSR in Arab Middle East, Karam and Jamali (2013: 61) argue that while it may be "unrealistic to expect too much of CSR, it is also unreasonable to expect too little". The authors acknowledge the role of CSR as an important building block of the more interconnected and egalitarian societies in that region.

Such a role for corporations may be seen as attractive by some, particularly with regard to topics such as gender. We noted earlier that a dialectical analysis of the relationship between Islam and gender roles likely over time will lead to a new synthesis in which women's roles in Islamic societies will change in ways that bring about greater economic participation. Such a perspective might be seen as consistent with Scherer and Palazzo's proposal that "some corporations do not simply follow powerful external expectations by complying with societal standards in legal and moral terms; they engage in discourses that aim at setting or redefining those standards and expectations in a changing, globalizing world and assume an 
enlarged political co-responsibility" (Scherer \& Palazzo, 2007: 1109). However, we note that there are some important differences between our account of dialectical processes and the political role of the corporation that arises from the Habermasian perspective of Scherer and Palazzo.

The essential difference, we propose, is the role of the corporation and whether it is a leading or supporting role. As we have noted, there is a discourse within Islam about the appropriate role of women, and this discourse will continue as Islamic societies interact with a globalizing world. Through their business activities and the perspectives they bring when they operate in Islamic societies, corporations implicitly are participating in that discourse. Consistent with their values and business goals, corporations may want to be supportive of egalitarian impulses within the societies in which they are operating. When it is possible to do so, the political role of the corporation can thus be to strategically engage with Islam and Islamic societies in ways that are supportive of gender egalitarianism, but not to take a leading role of pressing the dialogue or seeking social change. There is a danger that corporations that will take it upon themselves to try to construct other societies-with values that those societies have chosen-in their own images without regard for the choices that societies, Islamic and otherwise, have made.

While we acknowledge that Islamic societies are continually revisiting their own choices about gender roles, those choices are not a fait accompli. If business necessity, Muslim women's personal choices, and Islamic hermeneutics all support more egalitarian gender roles, then supporting them may not tantamount to an imposition of foreign values or a skirmish in the war of civilizations. Indeed, while we have argued that corporations should not deny Muslim women the opportunity to live and work according to their faith, it is important to consider whether corporations should comply with and even enforce a prevailing local norm that curtails women's liberties, especially if local women chafe against that norm. For instance, should a corporation enforce a local custom or law that requires women to wear the hijab, if some of that corporation's women employees do not find legitimate religious grounds to do so? Should a corporation honor local norms dictating that women employees serve only women customers, or that women hold no formal administrative authority over men? We argue that, in such instances, the heterogeneity of local norms and employee preferences may be accommodated, without allowing any single group or ideology, foreign or local, to infringe the personal space and judge the ethical conduct of others.

Indeed, the imposition of values from the outside, either directly or through undue participation in Islamic discourse, might backfire and make gender egalitarianism seem to be a Western idea, when as we have noted, there are egalitarian movements within Islam and support for gender egalitarianism within the Quran. In short, the economic role of women should not become another front in a supposed war of civilizations in which the welfare of women themselves are an afterthought. Here Spivak (1988: 310) notes that it is possible that in the debate "between patriarchy and imperialism, subject-constitution and object-formation, the figure of the women disappears, not into a pristine nothingness, but into a violent shuttling which is the displaced figuration of the 'third-world woman' caught between tradition and 
modernization.” In seeking to promote gender egalitarianism within Islamic societies, corporations should not seek to play such a central role that the free choices of women (and men) within those societies are not lost, thus relegating the wishes of women to the sideline.

\section{CONCLUSION}

In this article, we have sought to provide a more nuanced perspective on gender roles within the Islamic world. There is an egalitarian tradition within Islamic theology, much of which is only recently being recovered and used within MMCs. There is an increasing recognition of women's capabilities within and across Islamic societies. Women and men within Islamic societies are thus making pragmatic and personally faithful choices about the appropriate roles of women and men in the economic, social, and household spheres. Businesses therefore can and should operate in ways that are culturally appropriate and consistent with the economic capabilities of women.

\section{NOTES}

1. The Quranic verses provided in this paper are taken from the English translation by Abdullah Yusuf Ali, which is generally viewed as one of the most authentic translations in English.

2. The Scriptures are influential in adducing religious values as counterweights to the Western materialist schedule of interests and desires. Muslims, for instance, take the Scriptures very seriously (Esposito, 2002), so it is useful to note that the Scriptures permit an egalitarian interpretation.

3. The code of Islamic law derived from the Quran and the traditions of the Prophet Muhammad. Sharia is the contemporary legal interpretation of Islamic theology as applied to daily life and reference to it; however it is "a long, diverse, complicated intellectual tradition," rather than a "well-defined set of specific rules and regulations that can be easily applied to life situations" (Janin \& Kahlmeyer, 2007: 3). Therefore, sharia is not and should not be treated as equivalent to Islamic theology.

4. Islamic scholars generally agree that the Quran also specifies that women should receive half as much an inheritance as men (i.e. daughter gets half as much as son), however, this should be seen in the context in which man, not woman, is responsible to economically afford the family unit including spouse and children. Thus, it is important to situate any Islamic tradition within its larger textual and social contexts, e.g., the context of the seventh-century Arabia, or the interpretive context of medieval Islamic scholars who influenced the Quranic interpretation for centuries to come, or the contemporary economic or social context within which interpretations and translations are made and read.

5. However, this must not be misconstrued to suggest that a man cannot take care of domestic duties or that a woman cannot work outside the house. Subject to the Islamic values of female and male modesty, the Quran does not object to any such arrangement.

The primary concern for women's employment in Islam is per se not so much about the roles and jobs that are prescribed or proscribed for women in the workplace, because as such there is no such provision in the Quranic text which specifies such jobs and roles. The emphasis in Islam is instead upon maintaining a gender division of labor that does not violate the Islamic societal norms of work life balance.

\section{REFERENCES}

Abu-Shuqqah, A. 1990. Tahrir Al-Mar'ah Al-Muslimah Fi 'Asr Al-Risalah (in Arabic, vols. 1-6). Kuwait: Dar Al-Qalam.

Ahmed, L. 1992. Women and gender in Islam: Historical roots of a modern debate. New Haven, CT: Yale University Press. 
Al-Hibri, A. 1982. A study of Islamic herstory: Or, how did we ever get into this mess? Women's Studies International Forum, 5(2): 207-19. http://dx.doi.org/10.1016/0277-5395(82)90028-0

Ali, F. 2013. A multi-level perspective on equal employment opportunity for women in Pakistan. Equality, Diversity and Inclusion: An International Journal, 32(3): 289-309. http://dx.doi.org/10.1108/EDI-12-2012-0110

Ali, S. 2000. Gender and human rights in Islam and international law: Equal before Allah, unequal before men? The Hague: Kluwer Law International.

Alkire, S. 2002. Dimensions of human development. World Development, 30(2): 181-205. http://dx.doi.org/10.1016/S0305-750X(01)00109-7

Anderson, J. 2004. Does God matter, and if so whose God? Religion and democratization. Democratization, 11(4): 192-217. http://dx.doi.org/10.1080/135103404000236817

Armstrong, K. 1992. Muhammad: A biography of the Prophet. New York: Harper Collins.

Barlas, A. 2001. Muslim women and sexual oppression: Reading liberation from the Quran. Macalester International, 10(1): 117-46.

. 2002. "Believing women" in Islam: Unreading patriarchal interpretations of the Quran. Austin: University of Texas Press.

2006. Does the Quran support gender equality? Or, do I have the autonomy to answer this question? Keynote address at the Workshop on Islam and Autonomy, University of Groningen, November 24. Available online at http://asmabarlas.com /PAPERS/Groningen_Keynote.pdf, accessed 26 March 2012.

Bayes, J. H., \& Tohidi, N. (Eds.). 2001. Globalization, gender, and religion: The politics of women's rights in Catholic and Muslim contexts. Basingstoke: Palgrave Macmillan.

Beeku, R., \& Badawi, J. 2005. Balancing ethical responsibility among multiple organizational stakeholders: The Islamic perspective. Journal of Business Ethics, 60(2): 131-45. http://dx.doi.org/10.1007/s10551-004-8204-5

Benson, J. K. 1977. Organizations: A dialectical view. Administrative Science Quarterly, 22(1): 1-21. http://dx.doi.org/10.2307/2391741

Bracey, C. 2006. Getting back to basics: Some thoughts on dignity, materialism and a culture of racial equality. Chicano-Latino Law Review, 26: 1-40.

Bruckner, D. 2009. In defense of adaptive preferences. Philosophical Studies, 142(3): 307-24. http://dx.doi.org/10.1007/s11098-007-9188-7

Bukhari, S. 1959. Translation of the Sahih Al-Bukhari (trans. Muhamamd Muhsin Khan). Cairo: Mustafa Al-Babi Al-Halabi Press.

Conte, R., \& Castelfranchi, C. 1995. Cognitive and social action. London: UCL Press.

Crescentlife. n.d. Working women: Early Muslim women who would work. Available online at http://www.crescentlife.com/thisthat/feminist\%20muslims/working_women _during_early_islam.htm, accessed 17 June 2012.

DeSilver, D. 2013. World's Muslim population more widespread than you might think. Pew Research Centre. Available online at http://www.pewresearch.org/fact-tank/ 2013/06/07/worlds-muslim-population-more-widespread-than-you-might-think, accessed 17 January 2014. 
Easterlin, R. A. 2003. Do aspirations adjust to the level of achievement? A look at the financial and family domains. European Science Foundation Exploratory Workshop on Income, Interactions and Subjective Well-Being, Paris.

Esposito, J. 2002. What everyone needs to know about Islam. Oxford: Oxford University Press.

Eyerman, R. 1992. Modernity and social movements. In H. Haferkamp and N. J. Smelser (Eds.), Social change and modernity: 37-54. Berkley: University of California Press.

Gagnon, S., \& Cornelius, C. 2000. Re-examining workplace equality: The capabilities approach. Human Resource Management Journal, 10: 68-87. http://dx.doi.org/10.1111/j.1748-8583.2000.tb00007.x

Gallagher, S., \& Smith, C. 1999. Symbolic traditionalism and pragmatic egalitarianism: Contemporary evangelicals, families, and gender. Gender and Society, 13(2): 21133. http://dx.doi.org/10.1177/089124399013002004

Ghorbani, M., \& Tung, R. 2007. Behind the veil: An exploratory study of the myths and realities of women in the Iranian workforce. Human Resource Management Journal, 17: 376-92. http://dx.doi.org/10.1111/j.1748-8583.2007.00051.x

Giddens, A. 1990. Consequences of modernity. Cambridge: Polity Press.

1991. Modernity and self-identity. Self and society in the late modern age. Cambridge: Polity Press.

Hakim, C. 1998. Developing a sociology for the twenty-first century: Preference theory. British Journal of Sociology 49: 137-43. http://dx.doi.org/10.2307/591267

.1999. Models of the family, women's role and social policy: A new perspective from preference theory. European Societies, 1(1): 33-58.

http://dx.doi.org/10.1080/14616696.1999.10749924

. 2003. Models of the family in modern societies: Ideals and realities. Burlington, VT: Ashgate Publishing Company.

Hassan, R. 1994. Women's interpretation of Islam. In H. Thijssen (Ed.), Women and Islam in Muslim societies. The Hague: Ministry of Foreign Affairs Poverty and Development Program.

1999. An Islamic perspective. In K. Lebacqz (Ed.), Sexuality: A reader. Cleveland: Pilgrim Press.

Hekman, S. 1990. Gender and knowledge: Elements of a postmodern feminism. Boston: Northeastern University Press.

Hua, D. 2008. Speech by Hua Du, Country Director, Asian Development Bank, Bangladesh Resident Mission. Second National Women SME Entrepreneur Conference. Dhaka, February 13.

Hussain, A. 1987. Status of women in Islam. Lahore: Law Publishing Company.

Hyder, K. 2008. The support for women in Iran is tremendous. Daily Dawn (Karachi), 8 July.

Ibn Majah. 1952. Sunan Ibn Majah. Cairo: Dar Ihya' al Kutub al Arabiyah.

Janin, H., \& Kahlmeyer, A. 2007. Islamic law: The sharia from Muhammad's time to the present. Jefferson, NC: McFarland \& Co. 
Karam, C., \& Jamali, D. 2013. Gendering CSR in the Arab middle east: An institutional perspective. Business Ethics Quarterly, 23(1): 31-68.

http://dx.doi.org/10.5840/beq20132312

Keddie, N. (Ed.). 1996. Debating gender, debating sexuality. New York: New York University Press.

Kelan, E. K. 2008. Emotions in a rational profession: The gendering of skills in ICT work. Gender, Work and Organization, 15(1): 49-71.

Lewis, B. 1995. The middle east. London: Weidenfeld \& Nicolson.

Lukes, S. 1985. Emile Durkheim: His life and work, a historical and critical study. Stanford, CA: Stanford University Press

Marlow, L. 1997. Hierarchy and egalitarianism in Islamic thought. Cambridge: Cambridge University Press.

Mayer, D., \& Cava, A. 1993. Ethics and the gender equality dilemma for U.S. multinationals. Journal of Business Ethics, 12(9): 701-08. http://dx.doi.org/10.1007/BF00881384

Menon, N. 2002. Universalism without foundations? Economy and Society, 31(1): 15269. http://dx.doi.org/10.1080/03085140120109295

Mernissi, F. 1987. Beyond the veil: Male-female dynamics in modern Muslim society. Bloomington: Indiana University Press.

1991. Women and Islam: An historical and theological enquiry. Oxford: Blackwell.

1996. Women's rebellion and Islamic memory. London: Zed Publishers.

Metcalfe, B. D., and Rees, C. J. 2010. Gender, globalization and organization: Exploring power, relations and intersections: Guest editorial. Equality, Diversity and Inclusion: An International Journal, 29(1): 5-22. http://dx.doi.org/10.1108/02610151011019183

Miles, A. 1996. Integrative feminisms: Building global visions, 1960s-1990s. New York: Routledge.

Minai, N. 1981. Women in Islam: Tradition and transition in the middle east. London: John Murray.

Moghadam, V. 2009. Where are Iran's working women? Payvand's Iran News. 10 February. Available online at http://www.payvand.com/news/09/feb/1110.html, accessed 2 March 2013.

Moore, H. M. 2007. Visible through the veil: The regulation of Islam in American law. Sociology of Religion, 68: 237-51. http://dx.doi.org/10.1093/socrel/68.3.237

Nussbaum, M. 1999. Sex and social justice. Oxford: Oxford University Press. 2000. Woman and human development. Cambridge: Cambridge University Press. http://dx.doi.org/10.1017/CBO9780511841286

2001. Capabilities as fundamental entitlements: Sen and social justice. Paper presented at Conference on Sen's Work, University of Bielefeld, Germany.

2012. The new religious intolerance: Overcoming the politics of fear in an anxious age. Boston: Belknap Press.

http://dx.doi.org/10.4159/harvard.9780674065918 
Özbilgin, M. F., Syed, J., Ali, F., \& Torunoglu, D. 2012. International transfer of policies and practices of gender equality in employment to and among Muslim majority countries. Gender, Work and Organization, 19(4): 345-69. http://dx.doi.org/10.1111/j.1468-0432.2010.00515.x

Powell, G. N., \& Butterfield, D. A. 1994. Investigating the "glass ceiling" phenomenon: An empirical study of actual promotions to top management. Academy of Management Journal, 37(1): 68-86. http://dx.doi.org/10.2307/256770

Prophet's Last Sermon, The. n.d. Islam World. Available online at http://islamworld.net/ docs/sermon.html, accessed 20 December 2013.

Qizilbash, M. 2006. Capability, happiness and adaptation in Sen and J. S. Mill. Utilitas, 18(1): 20-32. http://dx.doi.org/10.1017/S0953820805001809

Qur'an. n.d. English translation of the meaning. Revised version of translation by Abdullah Yusuf Ali. Riyadh: The Presidency of Islamic Researches, King Fahd Holy Qur'an Printing Complex.

Robeyns, I. 2002. Gender inequality: A capability perspective. Unpublished Ph.D. thesis, Cambridge University.

Scherer, A., \& Palazzo, G. 2007. Towards a political conception of corporate responsibility: Business and society seen from a Habermasian perspective. Academy of Management Review, 32(4): 1096-1120.

Sen, A. 1992. Inequality re-examined. Oxford: Clarendon Press.

1993. Capability and well-being. In M. Nussbaum \& A. Sen (Eds.), The quality of life: $30-54$. Oxford: Clarendon Press.

1995. Gender inequality and theories of justice. In M. Nussbaum \& J. Glover (Eds.), Women, culture and development: A study of human capabilities: 259-73. Oxford: Oxford University Press.

1999. Development as freedom. Oxford: Oxford University Press.

Seo, M., \& Creed, W. E. 2002. Institutional contradictions, praxis, and institutional change: A dialectical perspective. Academy of Management Review, 27(2): 222-47.

Sidani, Y., \& Thornberry, J. 2013. Nepotism in the Arab world: An institutional theory perspective. Business Ethics Quarterly 23(1): 69-96.

http://dx.doi.org/10.5840/beq20132313

Spivak, G. C. 1988. Can the subaltern speak? In C. Nelson \& L. Grossberg (Eds.), Marxism and the interpretation of culture: 271-313. Urbana: University of Illinois Press.

Suchman, M. C. 1995. Managing legitimacy: Strategic and institutional approaches. Academy of Management Review, 20(3): 571-611.

Sugden, R. 2006. What we desire, what we have reason to desire, whatever we might desire: Mill and Sen on the value of opportunity. Utilitas, 18(1): 33-51. http://dx.doi.org/10.1017/S0953820805001810

Syed, J. 2008. A context specific perspective of equal employment opportunity in Islamic societies. Asia Pacific Journal of Management, 25(1): 135-51. http://dx.doi.org/10.1007/s10490-007-9051-6 
Syed, J., \& Ali, F. 2005. A historical perspective of Islamic modesty and its implications for Pakistani women at work. Paper presented at Women's History Conference, IFRWH, UNSW, Sydney.

2011. The white woman's burden: From colonial civilisation to third world development. Third World Quarterly, 32(2): 349-65.

http://dx.doi.org/10.1080/01436597.2011.560473

Syed, J., Ali, F., \& Winstanley, D. 2005. In pursuit of modesty: Contextual emotional labour and the dilemma for working women in Islamic societies. International Journal of Work, Organisation and Emotion, 1(2): 150-67.

http://dx.doi.org/10.1504/IJWOE.2005.008819

Syed, J., \& Murray, P. 2008. A cultural feminist approach towards managing diversity in top management teams. Equal Opportunities International, 27(5): 413-32. http://dx.doi.org/10.1108/02610150810882288

Syed, J., \& Pio, E. 2010. Veiled diversity: Workplace experiences of Muslim women in Australia. Asia Pacific Journal of Management, 27(1): 115-37.

http://dx.doi.org/10.1007/s10490-009-9168-x

Tatli, A., Vassilopoulou, J., \& Özbilgin, M. 2013. An unrequited affinity between talent shortages and untapped female potential: The relevance of gender quotas for talent management in high growth potential economies of the Asia Pacific region. International Business Review, 22(3): 539-53.

http://dx.doi.org/10.1016/j.ibusrev.2012.07.005

Tönnies, F. 1971. On sociology: Pure, applied and empirical (W. J. Cahnman and R. Heberle, Eds.). Chicago: University of Chicago Press

UNDP (United Nations Development Program). 2002. Arab human development report. New York: United Nations Publications.

Veenhoven, R. 2000. The four qualities of life: Ordering concepts and measures of the good life. Journal of Happiness Studies, 1(1): 1-39. http://dx.doi.org/10.1023/A:1010072010360

2002. Why social policy needs subjective indicators. Social Indicators Research, 58(1-3): 33-45. http://dx.doi.org/10.1023/A:1015723614574

Weber, M. 1958. The protestant ethnic and the spirit of capitalism. New York: Charles Scribner's Sons.

Wills, G. 2006. What Jesus meant. New York: Viking.

World Bank. 2008. Whispers to voices: Gender and social transformation in Bangladesh. Bangladesh Development Series Paper No. 22. Available online at www.worldbank .org.bd/bds, accessed 20 March 2013.

Young, I. M. 1990. Justice and the politics of difference. Princeton, NJ: Princeton University Press.

Zind, S. 2009. Iran 2009: Iranian women make gains, but barriers remain. VPR News, 5 February. Available online at http://www.vpr.net/news_detail/83908/, accessed 2 March 2013. 